\title{
Performance Evaluation of Continuous Aeration Process in Wastewater Treatment Contaminated with Heavy Metal of Chrome in Pilot Scale
}

\author{
AMIN ALLAH ZAREI ${ }^{1}$, HAMED BIGLARI ${ }^{2}$, KHALED SAMIEE ROUDI ${ }^{3}$ \\ and RAZIEH KHAKSEFIDI4, * \\ ${ }^{1}$ Department of Environmental Health Engineering, School of Public Health, Torbat Heydariyeh \\ University of Medical Sciences, Torbat Heydariyeh, Iran. \\ ${ }^{2}$ Department of Environmental Health Engineering, School of Public Health, Gonabad University of \\ Medical Sciences, Gonabad, Iran. \\ ${ }^{3}$ Department of Public Health, Khaf Integrated Health Education, Khaf, Iran. \\ ${ }^{4}$ Department of Environmental Health Engineering, School of Public Health, Zahedan University of \\ Medical Science, Zahedan, Iran. \\ *Corresponding author E-mail: r.khaksefidi110@gmail.com
}

http://dx.doi.org/10.13005/ojc/330649

(Received: July 29, 2017; Accepted: August 20, 2017)

\begin{abstract}
The increasing pollution from urban and industrial wastewaters with toxic metal ions is an issue of environmental concern. This study investigated the efficacy of continuous aeration process for the removal of heavy chromium metal. This study is an experimental study in which the variables of initial concentration of $\operatorname{Cr}(0.3,1,1.5 \mathrm{mg} / \mathrm{l})$, hydraulic retention time $(2,4,6,8 \mathrm{~h})$ and input $\mathrm{BOD}_{5}$ concentration $(100,150,200) \mathrm{mg} / \mathrm{l}$ of chromium was investigated in removal efficiency for continuous aeration reactor. The results showed that the chromium removal efficiency was 98.21 percent in 0.3 initial concentration, hydraulic retention time of $8 \mathrm{~h}$ and input $\mathrm{BOD}_{5} 200 \mathrm{mg}$. This study showed that the use of continuous aeration reactor has a high efficiency for the removal of chromium.
\end{abstract}

Keywords: Continuous aeration, Heavy metal, Chromium, Hydraulic retention time, Organic loading

An important class of environmental contaminants and serious human health risks are heavy metal and their concentrations in the environment have a direct relationship with urban sprawl and industrial development ${ }^{1}$. Heavy metals are under consideration because of their toxicity and tendency to accumulate in living organisms and also tend to react with sulfur and disrupt vital enzymes ${ }^{2-4}$. Heavy metals exist in metal industrial wastewater plating, mining, battery manufacturing plants, alloying, melting metals wastewater and may enter through the effluents of these industries in water sources ${ }^{5,6}$. One of the most important heavy metals is chromium that is considered as a hazardous pollutant in the environment ${ }^{7}$. Chromium through or waste disposal industries such as electroplating, tanning, dyeing and textile, metal processing ,leather, manure storage, etc. as the 
chromate and dichromate are leaks into water streams $^{8-12}$. $\mathrm{Cr}$ is found in nature as Hexavalent chromium and trivalent chromium $\mathrm{Cr}$ (VI). Hexavalent chromium compared with the highly toxic trivalent chromium is carcinogenic and mutagenic. The $\mathrm{Cr}(\mathrm{VI})$ was dissolved in water and can be very different $\mathrm{pH}$ bivalent anions such as chromate, dichromate and hydrogen chromate ${ }^{13,14}$. If long-term exposure accrued with high levels of chromium and Upper standard, it causes problems such as damage to the lungs, kidneys, liver, nervous tissue, skin and gastrointestinal tract in humans ${ }^{15,16}$. Standards for discharge wastewater in surface water is containing $\mathrm{Cr} 0.5 \mathrm{mg} / \mathrm{l}$, drained well $1 \mathrm{mg} / \mathrm{l}$ and for agriculture and irrigation is $1 \mathrm{mg} / \mathrm{I}^{17}$. Given the scarcity of water resources and the health and environmental risks of heavy metals such as chromium, practical and effective ways is considered to remove these contaminants from the environment ${ }^{18}$. Various methods are to be noted such as chemical precipitation, ion exchange, reverse osmosis, membrane processes, electrical precipitation, adsorption, coagulation, biological methods, etc. ${ }^{19-22}$. Most of these techniques have certain disadvantages such as high cost device operation, the need for additional chemicals, high energy consumption, need much space and not efficient at high concentrations ${ }^{20,23,24}$. In recent years, the biological assembly process has been widely studied. Micro- organisms such as algae, fungi, bacteria, yeast, actinomycetes etc. has been used as adsorbents for heavy metals. Microbiological methods for the absorption of metals from wastewaters and easier than other methods are very small allotment of more expensive high operational efficiency. Small particle size, rate of growth, proliferation, low density, high strength, low cost and their separation has caused researchers should pay more attention to microbial adsorbents $(25,26)$. Bioaccumulation is the removal of heavy metals using the metabolism of microorganisms which have the ability to accumulate heavy metals ${ }^{27}$. Many microorganisms have developed resistance to multiple metals and able to absorb within or outside the effect of these metals which pollutants on their cell microorganisms is the function of their concentration in the environment. Therefore, biological accumulate is a method that uses microorganisms and reduce pollution of heavy metals in the environment ${ }^{28}$. Activated sludge system with extended aeration is one of the refining process of aerobic suspended growth in the tank aerates the micro-level, high growth, and the stability and retention time on microbial lot, the treatment of wastewater with a high pollution is applicable ${ }^{29}$. The purpose of this study was to evaluate the performance of the continuous aeration process in wastewater contaminated with heavy metal chromium.

\section{MATERIALS AND METHODS}

This study is an experimental study in which a pilot scale reactor equipped with four diffusers for aeration. The reactor temperature, $\mathrm{pH}$ and DO were under control. Providing food for bacteria and the reactor inlet flow rate of the synthetic wastewater was used. For the construction of wastewater, Table 1 compounds were used (30-32). All materials used in this study were prepared from Merck, Germany. Returned to reactor wastewater treatment sludge as seeding Zahedan was added to each reactor. Then according to the specified volume, hydraulic retention time and the reactor inlet flow rate was adjusted. Continuous aeration was done dissolved oxygen concentrations were controlled by the DO to dissolved oxygen remains at a rate of about 3 milligrams per liter of. Permanently took reuse nutrients. According to the settled sludge in the settling tank (which it was calibrated) through specific sludge volume control valve is returned to the aeration basin. After three week favorable conditions provide for testing. The initial concentration of chromium (VI) was made using potassium dichromate and the concentration. BOD separately and simultaneously passed into the biofilm reactor was continuously aerated. In this study, the effect of initial $\mathrm{Cr}(\mathrm{VI})$ concentration factor $(0.3,1,1.5 \mathrm{mg} / \mathrm{l})$, hydraulic retention time $(2,4,6,8$ hours) and BOD $_{5}$ input $(100,150,200 \mathrm{mg} / \mathrm{l})$ was studied in heavy chromium (VI) removal. In all cases, the retention time was considered 30 days. up to $12 \mathrm{~h}$ and then the reaction should be absorbed by organisms in the sludge settling time of $4 \mathrm{~h}$ was given. It should be noted that the temperature of the reactor by the elements adjusted $35^{\circ} \mathrm{C}$ and $\mathrm{pH}$ environments using Hydrochloric Acid and Sodium Hydroxide 0.1 normal range of microbial growth that often the environment is neutral. Samples of wastewater containing $\mathrm{Cr}$ injected in reactors to absorption reaction accrue by organisms up to $12 \mathrm{~h}$ and then the reaction should be given the sludge settling time of 4 hours. The sampled output of the 
secondary settling tank was done and was passed via 0.45 micron Whatman filter. Then, by adding nitric acid, the acid is maintained under cold chain conditions to recitations were transferred to the laboratory. Chromium measurements were performed using atomic absorption device, Varian $220 \mathrm{~A}$ model. Equation 1 is used to calculate the efficiency of metal reduction:

Efficiency $=\frac{\text { inital concentration }=\text { secondary concentration }}{\text { initial concentration }}$

Table. 1: Materials used for the manufacture of synthetic wastewater $(\mathrm{g} / 100 \mathrm{ml})$

Materials

Chemical $\quad \mathrm{g} / 100 \mathrm{ml}$ formula

Ammonium acetate

Sodium bicarbonate

$\mathrm{CH}_{3} \mathrm{COONH}_{4} \quad 6$

Ferrous sulfate

Nickel sulfate

Iron chloride

Disodium hydrogen

phosphate

Potassium hydrogen $\mathrm{K}_{2} \mathrm{HPO}_{4}$ $\mathrm{NaHCO}_{3} \quad 10$

$\mathrm{FeSO}_{4} \cdot 7 \mathrm{H}_{2} \mathrm{O} \quad 1$

$\mathrm{NiSO}_{4} \cdot 7 \mathrm{H}_{2} \mathrm{O} \quad 0.05$

$\mathrm{FeCL}_{3} \cdot 6 \mathrm{H}_{2} \mathrm{O} \quad 0.05$

$\mathrm{Na}_{2} \mathrm{HPO}_{4} \cdot 7 \mathrm{H}_{2} \mathrm{O} \quad 3.3$

phosphate

Potassium dihydrogen $\mathrm{KH}_{2} \mathrm{PO}_{4}$

phosphate

Magnesium sulfate.

Cobalt chloride

Sodium sulfate.

$\mathrm{SSO}_{4} \cdot 7 \mathrm{H}_{2} \mathrm{O}$

0.004

Calcium chloride

0.001

$\mathrm{CaCL} 2$

0.3

\section{raw wastewater tank}

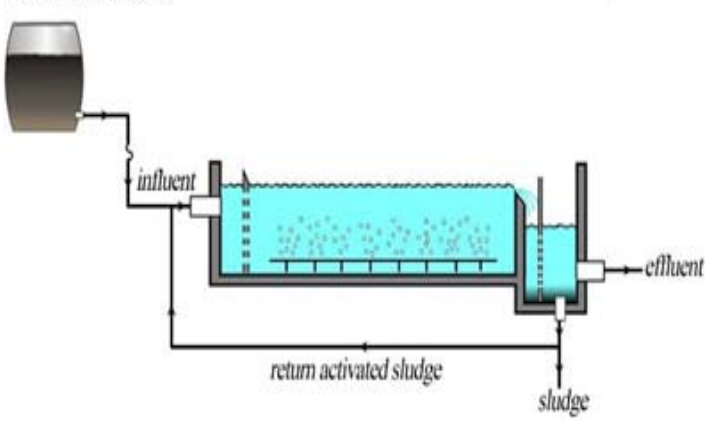

Fig 1. Schematic of the reactor used in this study

\section{RESULTS AND DISCUSSION}

Effect of hydraulic retention time on the removal and input $\mathrm{BOD}_{5}$ of chrome removal in continuous aeration reactor

Continuous aeration efficiency for the removal of heavy metal chromium from wastewater by biological methods of sewage pollution as well as reduce the system was studied. Fig. 2-4 show that the continuous aeration reactor, increasing the hydraulic retention time, increases removal rates at initial chromium concentration, but along the increase of chromium concentration in the reactor, the efficiency decreases. The results are such that the initial concentration of $\mathrm{Cr} 0.3 \mathrm{mg} / \mathrm{l}$, the highest removal rates are observed after $8 \mathrm{~h}(98.21 \%)$. But with increasing initial concentration of chromium to 1 and $1.5 \mathrm{mg} / \mathrm{l}$, the elapsed time was $4 \mathrm{~h}$, the highest levels of chromium removal are achieved. Increase the amount of chromium for microorganisms causing microorganisms to rapidly absorb it from the environment and soon lots to remove it and continued to decline chromium concentration with increasing hydraulic retention time is used for microorganisms and removal efficiency is reduced compared to before. Hydraulic retention time is one of the important parameters of the operation of biological systems while providing adequate contact time between active microbial mass and treatment material, preventing swept mass of the cell away. Reducing the hydraulic retention time, there is no sufficient contact time between the metal chromium and microorganisms and not decomposition of chromium (VI) is removed from the reactor. Chua and et al., in a study conducted in 1998, concluded that in less hydraulic retention times, capacity in the presence of organic matter in terms of COD $\mathrm{Cr}$ is higher than the hydraulic retention time, the removal efficiency is a low. Namely the hydraulic retention times of 2 and 2.5 days in the presence of chromium removal decreased but slightly increased hydraulic retention time of 5 days removed (33). In a study of civil and colleagues in 1390 , the results indicate that increasing the hydraulic retention time, COD removal efficiency increased and the best removal efficiency of hydraulic retention time of 8 hours and also increasing the COD removal efficiency decreased ${ }^{34}$. 


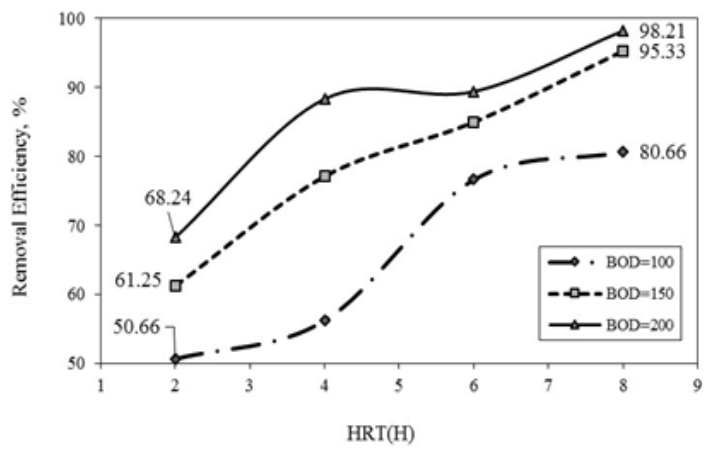

Fig. 2. Effect of $H R T$ and input $B O D_{5}$ in $\mathrm{Cr}$ removal (concentration of $\mathrm{Cr} 0.3 \mathrm{mg} / \mathrm{l}$ )

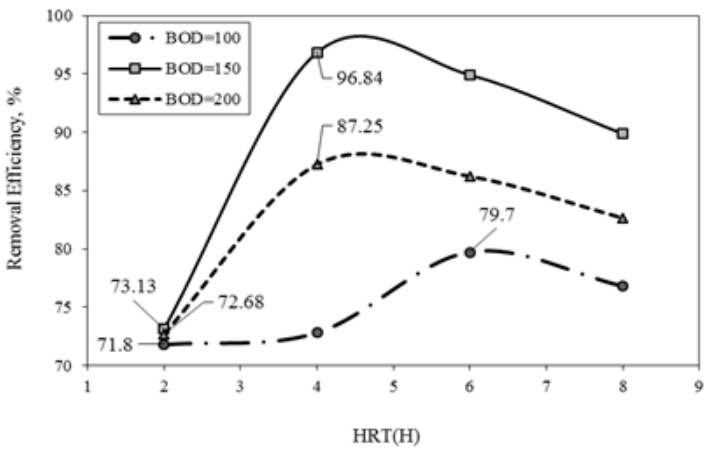

Fig. 3. Effect of HRT and input BOD $\mathrm{D}_{5}$ in $\mathrm{Cr}$ removal ( $\mathrm{Cr}$ concentration of $1 \mathrm{mg} / \mathrm{ml}$ )

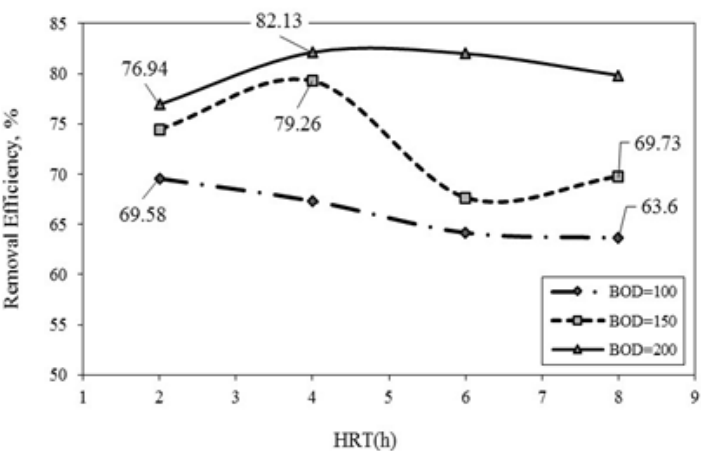

Fig. 4. Effect of $H R T$ and input $B O D_{5}$ in $\mathrm{Cr}$ removal ( $\mathrm{Cr}$ concentration of $1.5 \mathrm{mg} / \mathrm{ml}$ )

Effect of input $\mathrm{BOD}_{5}$ and initial concentration of chromium in continuous aeration reactor.

Figures 5-8 also show that increasing the concentration of organic load into the reactor in the presence of a fixed concentration of heavy metal, effectively increases the efficiency of the reactor. As the organic loading rate of chromium removal at an initial concentration of $200 \mathrm{ppm}, \mathrm{Cr} 0.3 \mathrm{mg}$ of hydraulic retention time of $8 \mathrm{~h}$ was about 98.21 percent. In aerobic wastewater treatment systems, if compliance with the emission of microorganisms, whereby the ability to absorb and metabolize organic loading will be within a certain range. However, it should be noted that the organic load increases over the span causes the growth of cell mass and their failure to form biological Fluke, most in the wastewater of organic load to be viewed. Previous studies showed that increasing the organic loading will increases substrate ${ }^{35}$. In the study that mineral cartridge used as biofilm support biological treatment of wastewater, the results showed that with increasing organic loading remains in constant retention time, the system efficiency increases in substrate remove ${ }^{36}$.

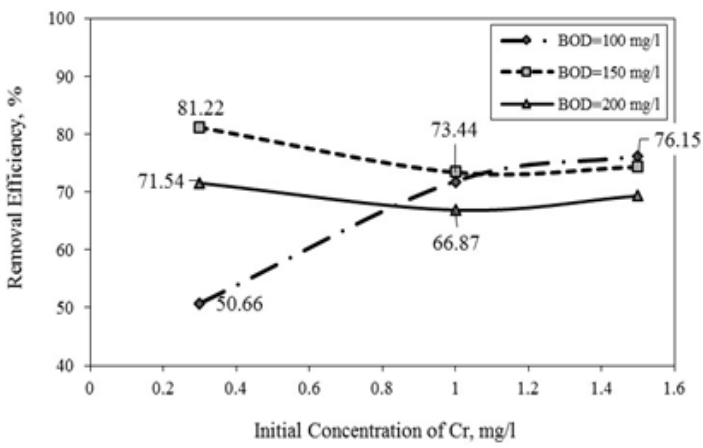

Fig. 5. Effect of $B O D_{5}$ input $(\mathrm{mg} / \mathrm{l})$ and the initial concentration of chromium in hydraulic retention time of 2 hours

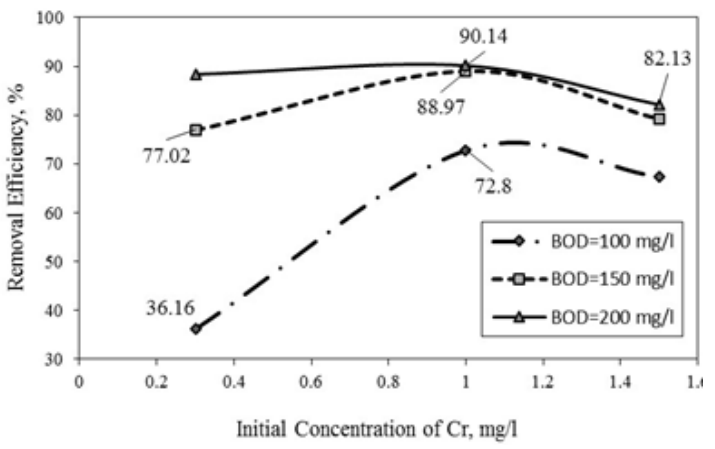

Fig. 6. Effect of $B O D_{5}$ input $(\mathrm{mg} / \mathrm{l})$ and the initial concentration of chromium in hydraulic retention time of 4 hours

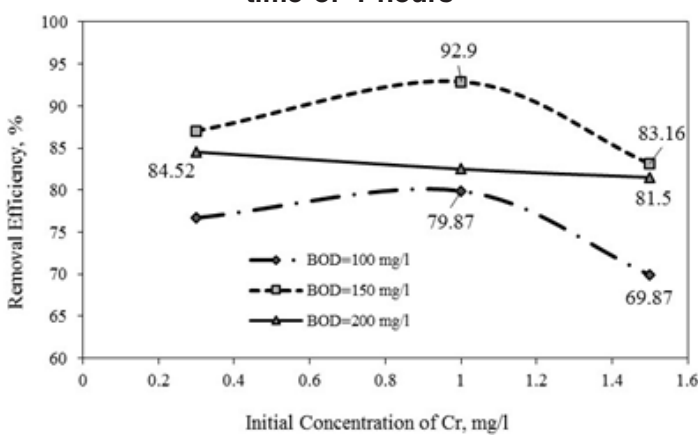

Fig. 7. Effect of $B O D_{5}$ input $(\mathrm{mg} / \mathrm{l})$ and the initial concentration of chromium in hydraulic retention time of 6 hours 


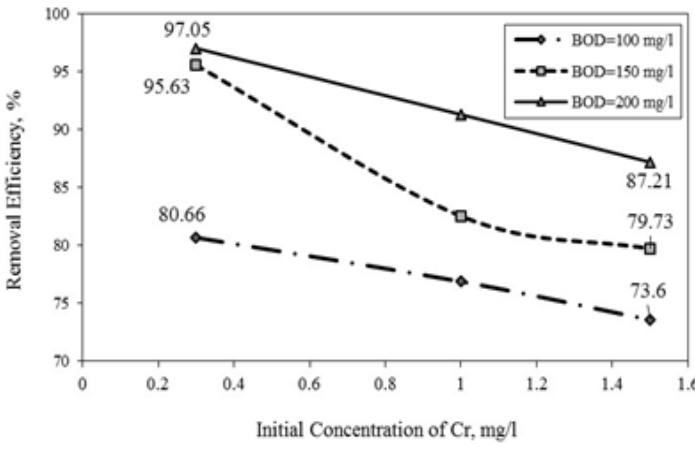

Fig 8. Effect of $B O D_{5}$ input $(\mathrm{mg} / \mathrm{l})$ and the initial concentration of chromium in hydraulic retention time of 8 hours

Effect of hydraulic retention time and the initial concentration of chromium in chromium removal in continuous aeration reactor

As Fig 9-11 shows, with increasing chromium concentration in the reactor, continuous aeration, the removal of chromium is reduced. So that the feed concentration $1.5 \mathrm{mg} / \mathrm{l}$ in input $\mathrm{BOD}_{5}$ and $200 \mathrm{ppm}$ and retention time of $8 \mathrm{~h}$, the amount of chromium removal 12.8 percent lower than the concentrations in the initial $0.3 \mathrm{mg} / \mathrm{l}$ concentration and with the same hydraulic retention time and input $\mathrm{BOD}_{5}$. The results show that high concentrations of chromium (VI) are a deterrent for the growth of microorganisms and microbial growth is slow. Another reason for the slowdown in fixed-time is organic foods limits the number of microorganisms. Given a fixed amount of food, increasing the number or amount does not exceed the growth of microorganisms, because does not provide enough food. Studies on the removal of pollutants using pumice stone as a fixed bed biofilm showed that increasing the concentration of contaminants into the reactor, reduced system performance ${ }^{35}$. In another study, the effect of the organic load changes on the removal efficiency of activated sludge biological reactor, propylene glycol has been

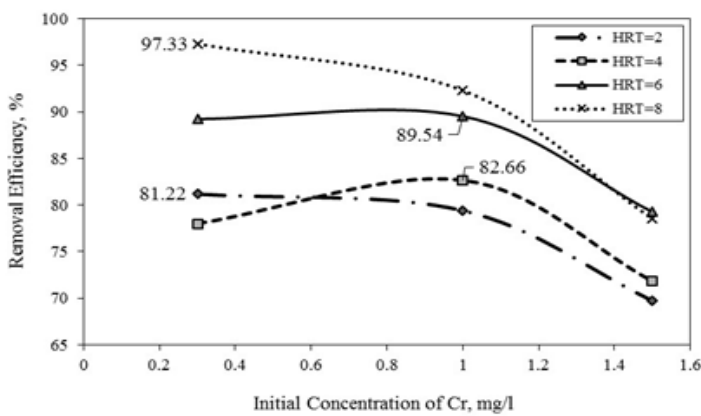

Fig. 9. Effect of HRT and the initial concentration Chromium in initial BOD $_{5}$ of $100 \mathrm{mg} / \mathrm{l}$

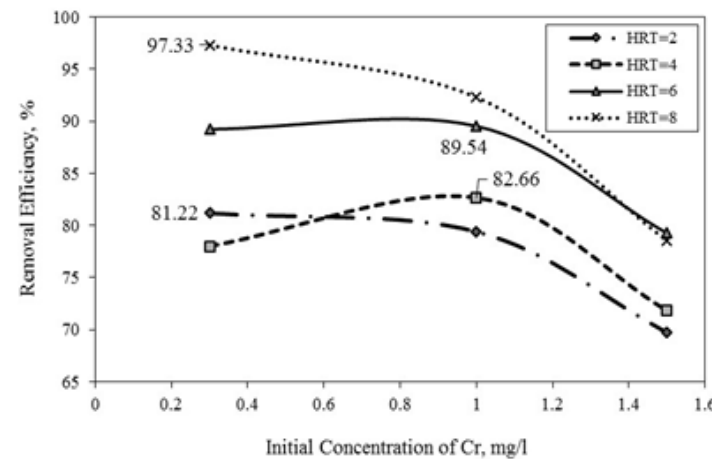

Fig. 10. Effect of HRT and the initial concentration Chromium in initial BOD $_{5}$ of $150 \mathrm{mg} / \mathrm{l}$

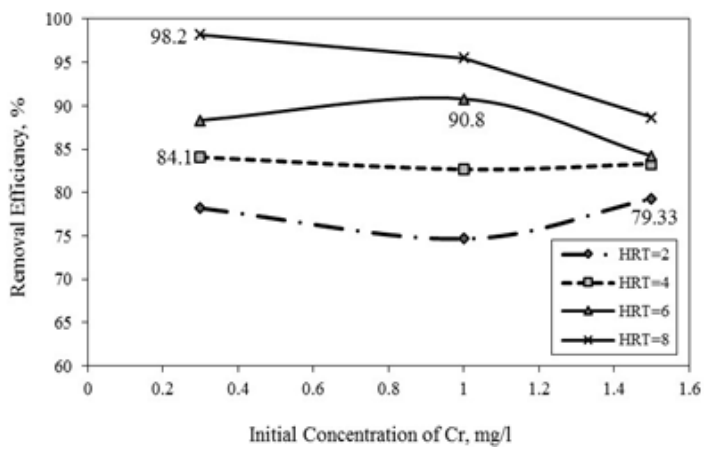

Fig. 11. Effect of HRT and the initial concentration Chromium in initial BOD $_{5}$ of $200 \mathrm{mg} / \mathrm{l}$

studied concluded that increasing concentrations of input propylene glycol, substrate removal efficiency is reduced ${ }^{37}$.

\section{CONCLUSIONS}

The results showed that $\mathrm{Cr}(\mathrm{VI})$ removal by continuous aeration process is very dependent to input organic loading, hydraulic retention time of chromium concentration in the reactor and the maximum efficiency of the $\mathrm{Cr} 0.3,1$ and $1.5 \mathrm{mg} / \mathrm{l}$ in organic input load retention time of 8 hours and $200 \mathrm{mg}$ is equal to $98.21,82.67$ and 79.84 percent respectively. Therefore, continuous aeration method can be used to remove chromium from industrial wastewater, as a useful, simple and high performance used in water and wastewater industry.

\section{ACKNOWLEDGMENTS}

Hereby is appreciated to everyone who helped us in this study and we appreciate the Deputy of Research and Technology of Medical Sciences, Zahedan for the financial support of this research and also to provide the necessary facilities (project Number 5948). 


\section{REFERENCES}

1. Ma, Y.; Egodawatta, P.; McGree, J.; Liu. A.; Goonetilleke, A. Sci. Total Environ. 2016, 557558,764-772.

2. Malakul, P.; Srinivasan, K. R.; Wang, H. Y. Ind. Eng. Chem. Res. 1998, 37(11), 4296-4301

3. Mohan, D.; Singh, K. P. Water Res. 2002, 36, 2304-2318.

4. Xu, P.; Liu, L.; Zeng, G.; Huang, D.; Lai, C.; Zhao, M.; Huang, C.; Li, N.; Wei, Z.; Wu, H.; Zhang, C.; Lai, M.; He, Y. Appl. Microbiol Biotechnol. 2014, 98,6409-6418.

5. Verma, A.; Kumar, SH.; Kumar,S. J. Environ. Chem. Eng. 2016, 4(4), 4587-4599.

6. Andaleeb, F.; Anjum Zia, M.; Ashraf, M. J. Environ. Sci. 2008, 20, 1475-1480.

7. Rand, G. M. Fundamentals of aquatic toxicology, Second edition, Ecological Services Inc. 1995, 23, 338.

8. Gupta, VK.; Shrivastava, AK.; Jain, N. Water Res. 2001, 35(17),4079-85. 5.

9. Ayangbenro, AS.; Babalola, O. Int. J. Environ. Res. Public Health. 2017,14(1). 94.

10. Mohamed, A.; Nasser, W. S.; Osman, T. A.; Toprak, M. S.; Muhammed, M.; Uheida, A. J. Colloid Interface Sci. 2017, 505, 682-691.

11. Chao, H.; Runhu, Z.; Fang, B.; Ping, L.; Xiangfeng, L. Chin. J. Chem. Eng. 2016, 25(2), 153-158.

12. Hengli, X.; Haidong, Z.; Yan, X.; Min, Y.; Xiaolian, J.; Jiale, H.; Qingbiao, L.; Daohua, S. Sep. Purif. Technol. 2017, 174, 466-473.

13. Asadi, A.; Dehghani, M.; Zare, M; Rahmani, A.; Golestani far, H.; North Khorasan Uni. Med. Sci. J. 2011, 3(4), 7-13.

14. Yasemin, S.; Ayten, O. Process Biochem. 2005, 40(5), 1895-1901.

15. Athanasios, G. T.; Evina, K.; Simos, M.; Vasilis, D.; Pantelis, P.; Evangelia, A. P.; Katherine, J. H. Appl. Clay Sci. 2017, ISSN 0169-1317.

16. Bianca, M.; Ana, C. G.; Mariliz, G. Process Saf. Environ. Prot. 2015, 95, 195-201.

17. Rao, K.S.; Mohapatra, M.; Anand, S.; Venkateswarlu, P. Sci. Tech. 2010, 2(7), 81-103.

18. Malkoc, E.; Nuhoglu, Y. J. Hazard. Mater.
2005, B127, 120-128.

19. Zouboulis, A. I.; Matis, K. A. Crit. Rev. Sci. Tech. 1997, 27(3),195-235.

20. Srivastava, S.K.; Gupta, K.V.; Mohan, D. J. Envir. Engrg. 1997, 5, 461-468.

21. Papageorgiou, S. K.; Katsaros, F. K.; Kouvelos, E. P.; Nolan, J. W.; Le, H.; Kanellopoulos, N. K. J. Hazard. Mater. 2006, 137, 1765-1772.

22. Afsharnia, M.; Saeidi, M.; Zarei, A.; Narooie, M. R.; Biglari. Electronic physician. 2016, 8(11), 3248-3256.

23. Dizgea, N.; Keskinlera, B.; Barlas, H. J. Hazardous Materials. 2009, 167, 915-926.

24. Bazrafshan, E.; Zarei, A. A.; Kord Mostafapour, F. Desalin. Water Treat. 2015, 1-11.

25. Ulaganathan, S.; Govindan, V. Environ. Prot. Eng. 2013, 39(3), 21-28.

26. Das, N.; Vimala, R.; Karthika, P.Indian J. Biotechnol. 2008, 7, 159-169.

27. Lefcort, H.; Aguon, M. Q.; Bond, K. A.; Chapman, K. R.; Clark, J.; Kornachuk, P.; Lang, B. Z.; Martin, J. C. Arch. Environ. Contam. Toxicol. 2002, 43, 34-41.

28. Metcaf and Eddy. Wastewater Engineering: Tretment, Disposal, Reuse Tata McGrowHill,4th, New Delhi, 2003.

29. Zeinaddine, H. R.; Ebrahimi, A.; Alipour, V.; Rezaei, L. J. Health Sci. Surveillance Sys. 2013, 1(2), 89-93.

30. Cadavid, D. L.; Zaiat, M.; Foresti, E. Water Sci. Technol. 1999, 39, 99-106.

31. Stefan, H.;Walter, T. J. Biotechno. 2001, 92(2), 95-101.

32. Chua, H. Sci. Total Environ. 1998, 214, 239-245.

33. Maleki, A.; Bahmani, P.; Ghahremani, A. Sci. J. Kurdistan Univ. Med. Sci. 2010, 48-55.

34. Sharbat Maleki, M.; Borghei, M.; J. Water Wastewater. 2004, 56, 62-72.

35. Kavoussi, A.; Borghei, M., Environ. Sci. 2004, 8, 29-42.

36. Farzadkia, M.; Rezaei Kalantari, R.; Mousavi,G.; Jarfy, S.; Gholami, M. Sci. Environ. Techno. 2008, 11(2), 98-112. 